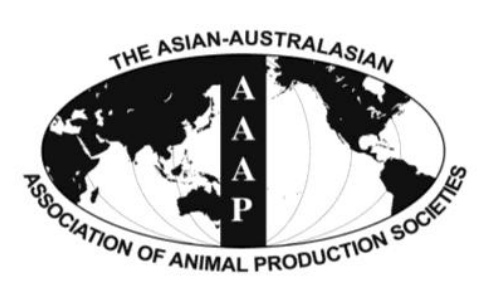

\title{
Prolificacy and Its Relationship with Age, Body Weight, Parity, Previous Litter Size and Body Linear Type Traits in Meat-type Goats
}

\author{
Avijit Haldar*, Prasenjit Pal ${ }^{1}$, M. Datta, Rajesh Paul, Saumen K. Pal, Debasis Majumdar ${ }^{2}$, \\ Chanchal K. Biswas ${ }^{2}$, and Subhransu Pan ${ }^{3}$ \\ ICAR Research Complex for North Eastern Hill Region, Tripura Centre, \\ Agartala, Lembucherra- 799210, West Tripura, India
}

\begin{abstract}
Data on age and body weight at breeding, parity, previous litter size, days open and some descriptive body linear traits from 389 meat-type, prolific Black Bengal goats in Tripura State of India, were collected for 3 and 1/2 years (2007 to 2010) and analyzed using logistic regression model. The objectives of the study were i) to evaluate the effect of age and body weight at breeding, parity, previous litter size and days open on litter size of does; and ii) to investigate if body linear type traits influenced litter size in meat-type, prolific goats. The incidence of $68.39 \%$ multiple births with a prolificacy rate of $175.07 \%$ was recorded. Higher age $(>2.69$ year), higher parity order (>2.31), more body weight at breeding $(>20.5 \mathrm{~kg})$ and larger previous litter size $(>1.65)$ showed an increase likelihood of multiple litter size when compared to single litter size. There was a strong, positive relationship between litter size and various body linear type traits like neck length $(>22.78 \mathrm{~cm})$, body length $(>54.86 \mathrm{~cm})$, withers height $(>48.85 \mathrm{~cm})$, croup height $(>50.67$ $\mathrm{cm})$, distance between tuber coxae bones $(>11.38 \mathrm{~cm})$ and distance between tuber ischii bones $(>4.56 \mathrm{~cm})$ for discriminating the goats bearing multiple fetuses from those bearing a single fetus. (Key Words: Goat, Black Bengal, Prolificacy, Linear Type Traits, Litter Size, Pregnancy)
\end{abstract}

\section{INTRODUCTION}

Linear traits are currently used for classifying goat breeds (Yakubu et al., 2010) and thus suggested for the inclusion of linear dimensions in breeding programmes of goats (Wiggans and Hubbard, 2001). Where genetic

* Corresponding Author: Avijit Haldar. Animal Reproduction Division, ICAR Research Complex for North Eastern Hill Region, Tripura Centre, Agartala, Lembucherra- 799210, West Tripura, India. Tel: +91-9436464223, Fax: +91-381-326846, E-mail: avijit_vet@rediffmail.com

1 College of Fisheries, Central Agricultural University, Lembucherra- 799210, West Tripura, India.

${ }^{2}$ Faculty of Agriculture, Bidhan Chandra Krishi Viswavidyalaya, Mohanpur, Nadia- 741252, West Bengal, India.

${ }^{3}$ Department of Livestock Production Management, West Bengal University of Animal and Fishery Sciences, 37, K. B. Sarani, Kolkata- 700037, West Bengal, India.

Submitted Oct. 18, 2013; Revised Nov. 17, 2013; Accepted Dec. 17, 2013 evaluation has still limited use in developing countries, identification of some descriptive linear traits may be useful and farmers' friendly tools for selecting goats with desirable characters.

Increasing kid production is of great interest to goat producers and thus, prolificacy is an economically important trait. Despite the wide use of evaluation for type in goats, little is known about the association between body conformation and some reproductive traits in this species. Linear type traits like physical strength, less sloped rump angle show positive relationships with litter size in dairy goats (Mellado et al., 2008). Although ultrasonographic scanning is used for the prediction of fetal number in goats (Abdelgafar et al., 2007), there is a dearth of knowledge on phenotypic descriptors to differentiate the pregnant goats bearing single or multiple fetuses under field conditions. Determination of fetal number during pregnancy in prolific goat breed is always helpful for differentiating the pregnant goats bearing single or multiple fetuses that aid in care and

Copyright (? 2014 by Asian-Australasian Journal of Animal Sciences This is an open-access article distributed under the terms of the Creative Commons Attribution Non-Commercial License (http://creativecommons.org/licenses/by-nc/3.0/), which permits unrestricted non-commercial use, distribution, and reproduction in any medium, provided the original work is properly cited. 
management to prevent pregnancy toxemia, dystocia and ensure the optimal birth weights and survivability of kids born to goats bearing multiple fetuses (Karen et al., 2006; Moallem et al., 2012). To date, there is an inadequate knowledge on the association between descriptive linear traits and the pregnant goats bearing single or multiple fetuses. A comprehensive description of phenotypic traits for differentiating the goats bearing single and multiple fetuses is thus urgently needed. Black Bengal goat is a small-sized, meat type, early maturing, non-seasonal and prolific breed (Acharya, 1982), in eastern and north eastern regions of India (Zeshmarani et al., 2007), Bangladesh (Rahman et al., 2006) and also in Pakistan (Khanum et al., 2007). This goat breed is famous for its quality of meat and leather with high fecundity. We thus aimed to evaluate the effect of age and body weight at breeding, parity, previous litter size and days open on litter size of does; and to test the hypothesis that body linear type traits might be associated to litter size in prolific goats.

\section{MATERIALS AND METHODS}

\section{Study area}

The study area included 23 villages in 3 districts (West Tripura, South Tripura and Dhalai) of Tripura state (longitude: $91^{\circ} 30^{\prime} \mathrm{E}$; latitude: $23^{\circ} 45^{\prime} \mathrm{N}$ ) in the northeastern region of India. Two-stage stratified random sample survey (consisting of village as strata- 1 and animal within village as strata- 2) was conducted on 389 pregnant Black Bengal goats for the collection of monthly phenotypic data during 5 months period of pregnancy between June 2007 to December 2010 for 3 and 1/2 years. Care was taken to select villages located in isolation to minimize genetic linkage among the animals. The average annual rainfall for these areas is $2,100 \mathrm{~mm}$. The climate is hot and humid with temperature ranging from $10^{\circ} \mathrm{C}$ in winter to $35^{\circ} \mathrm{C}$ in summer.

\section{Experimental animals}

In the villages, goats are reared in small groups of 2 to 5 goats per household. The animals are allowed for free grazing during the day on natural pasture, tree lopping and scavenging on kitchen waste when available. The female goats are mated naturally by the bucks available in the village. The study commenced with the primary visits to identify individual female goats and their owners. The goats having certain prominent physical characteristics like small size, deep body, straight, convex or concave head, short legs, thin and shiny hair coat of any single colour (black, white and brown) or mixed (combination of any two of the pure colours), erect or pendulous ears, curved or straight horn, short tail were identified as Black Bengal goats (Sahoo et al., 2005). The selected animals were free from diseases and had at least one previous kidding but less than 6 kiddings.
Goats between their first and second month of pregnancy, as reported by the owners, were selected and identified by a neck tag with certain number. The animal's feeds were supplemented with standard concentrate mixture at $200 \mathrm{gm}$ per head per day, vitamins and mineral mixture and examined regularly by a veterinarian during the study period.

\section{Data collection}

Herd details were recorded on an individual data card consisted of number of females, kids and whether buck maintained in the herd, age of the female goats, parity, last date of kidding, previous litter size, current date/month of last breeding etc. Sixteen phenotypic variables measured included ear length, neck length, head rump length (HRL), head rump curve length (HRCL), body length (BL), sacral length (SL), body weight (BW), heart girth (HG), punch girth (PG), pelvic triangle area (PTA), withers height (WH), croup height $(\mathrm{CH})$, clearance at sternum $(\mathrm{CS})$, clearance at udder (CU), distance between tuber coxae bones (DTC) and distance between tuber ischii bones (DI). The length, height and circumference measurements (centimeters) were taken using a measuring tape. The measurements (centimeters) of DTC and DI were done using a calibrated wooden caliper. Body weight $(\mathrm{kg})$ was taken using a spring balance. All measurements were collected from the goats at the third week of each month during five months pregnancy period in the morning before the animals were released for grazing. Measurements were recorded on an individual data sheet. Does that aborted during the study period were excluded from the experiment. Finally, 389 does completed the term and gave birth to live kid(s). Each individual doe was sampled once only. The numbers of single, twin and triplet pregnancies were 123, 240 and 26, respectively. Litter size (LZ) was defined as the number of kid(s) born by each goat and considered at 3 levels: single, twin and triplet births. Prolificacy was calculated as the percentage of number of kids born on total number of does delivered according to the following equation.

Prolificacy (\%)

$=($ No. of kids born $/$ No. of does delivered $) \times 100$

\section{Statistical analysis}

Data were analyzed in two steps. In the first step, age, parity, previous litter size, days open, body coat colour and data of sixteen phenotypic variables covering ear length, neck length, head rump length, head rump curve length, body length, sacral length, body weight, heart girth, punch girth, pelvic triangle area, withers height, croup height, clearance at sternum, clearance at udder, distance between tuber coxae bones and distance between tuber ischii bones collected on 389 does were analyzed using multiple 
stepwise logistic forward regressions (PROC LOGISTIC; SAS, 2012) to do the stepwise selection for identifying the prognostic factors for litter size. The model used was the logistic regression (LR) model:

$$
\log \left[\frac{\theta(x)}{1-\theta(x)}\right]=\alpha+\beta_{1} x_{1}+\beta_{2} x_{2}+\ldots+\beta_{i} x_{i}
$$

where, litter size is the dependent variable; age, parity, previous litter size, days open, ear length, neck length, body weight, head lump length, head rump curve length, body length, sacral length, wither height, croup height, heart girth, punch girth, clearance at udder, clearance at sternum, pelvic triangle area, distance between tuber coxae bones, distance between tuber ischii bones are the predictor variables that ' $x$ ' represents; $\alpha=$ intercept of the model and $\beta=$ the coefficient of predictor variables.

LR enters predictor variables in a stepwise manner; it will also fit specified models or perform forward selection of variables. At each step in the stepping process, an attempt was made to remove any insignificant variables from the model before adding a significant variable to the model. A significance level of 0.3 was required to allow a variable to enter into the model, and a significance level of 0.35 was required for a variable to stay in the model. The step selection was based on the maximum likelihood ratio. The evaluation of the logistic regression model was done by Hosmer and Lemeshow Goodness-of-Fit Test in the logistic procedure.

The response variable chooses litter size $=1$ (when a pregnant goat carrying more than one kid) as against litter size $=0$ (when a pregnant goat carrying one kid only) so that the probability of litter size is modeled. There were some missing data for some individuals during the five month period study. Hence, an average value of monthly data for each linear trait was considered for analysis. From stepwise logistic regressions, some traits were emerged as the prognostic factors that could influence litter size significantly.

In the second step, we wanted to find out certain point of measurement of various identified factors that could indicate the likelihood of multiple fetuses in does during pregnancy. An average value for each identified (stepwise logistic procedure) trait was determined for classifying the does into one of two categories of identified traits: those above or below average value for each trait. The null hypothesis that odds of prolificacy (does carrying two or more fetuses vs. does carrying single fetus) is the same in does classified as above or below average for different identified traits was tested by using logistic regression model (PROC LOGISTIC; SAS, 2012). The identified potential traits associated with litter size were included in the model as independent variables. The resulting values (odds ratios) were then interpreted as decisive factor. An odd ratio of ' 1 ' indicates that the factor examined does not alter the chance of single or multiple fetuses. Odd ratios $>1$ imply a direct association with an increase likelihood of multiple fetuses. Odd ratios $<1$ imply an inverse association with the likelihood of multiple fetuses.

\section{RESULTS AND DISCUSSION}

\section{Prolificacy}

The percent of Black Bengal does showing different birth type based on kidding size is presented in Table 1. The litter size proportions for single, twin and triplet were $31.61 \%, 61.70 \%$ and $6.69 \%$, respectively. The present survey recorded the birth of 681 kids from 389 kidding does, averaging 1.75 kids per doe and registering prolificacy rate of $175.07 \%$. The average litter size being 1.75 in this study is quite comparable with some world prolific goat breeds including Nubian, Pygmy, American Alpine, French Alpine, Saanen and Toggenburg with the average litter size of 2.0, 1.9, 1.9, 1.7, 1.7 and 1.6, respectively (Amoah et al., 1996), suggesting that Black Bengal goats are prolific goat breed. Our findings on $68.39 \%$ multiple births, of which $61.70 \%$ were twinning agree with the previous record of Hassan et al. (2007) who reported the incidence of 56.3\% twinning births in Black Bengal goats in neighboring Bangladesh.

\section{Factors influencing litter size}

Table 2 provides a summary of various descriptive linear traits including age, parity, previous litter size and days open included in the analysis. A limited work on the effect of age, body weight, parity and descriptive linear traits on prolificacy has been reported in small ruminants, especially goats. The result of stepwise logistic regression analysis is presented in Table 3 that shows the factors influencing litter size in pregnant does. Withers height was the best discriminating factor between does carrying multiple fetuses and does bearing single fetus during pregnancy. Distance between tuber coxae bones, neck length, body length, croup height, body weight and age

Table 1. Indian Black Bengal goats with different litter size groups and prolificacy

\begin{tabular}{|c|c|c|c|c|c|c|}
\hline & \multicolumn{3}{|c|}{ Litter size } & \multirow{2}{*}{ Total kids born } & \multirow{2}{*}{$\begin{array}{c}\text { Average } \\
\text { kid born/doe }\end{array}$} & \multirow{2}{*}{ Prolificacy $(\%)$} \\
\hline & Single & Twin & Triplet & & & \\
\hline Number of animal & 123 & 240 & 26 & 681 & 1.75 & 175.07 \\
\hline$\%$ of animal & 31.61 & 61.70 & 6.69 & & & \\
\hline
\end{tabular}


Table 2. Descriptive statistics for different body linear traits including age, parity in meat-type, prolific Black Bengal goats in India

\begin{tabular}{lc}
\hline Trait & Mean \pm SD \\
\hline Age (yr) & $2.69 \pm 1.27$ \\
Parity (No.) & $2.31 \pm 1.45$ \\
Previous litter size (No.) & $1.65 \pm 0.67$ \\
Days open (d) & $104.11 \pm 41.54$ \\
Ear length (cm) & $12.40 \pm 1.23$ \\
Neck length (cm) & $22.78 \pm 3.32$ \\
Body weight (kg) & $20.50 \pm 4.68$ \\
Head rump length (cm) & $57.15 \pm 5.16$ \\
Head rump curve length (cm) & $62.14 \pm 4.86$ \\
Body length (cm) & $54.86 \pm 6.60$ \\
Sacral length (cm) & $12.80 \pm 1.26$ \\
Withers height (cm) & $48.85 \pm 3.35$ \\
Croup height (cm) & $50.67 \pm 3.26$ \\
Heart girth (cm) & $62.70 \pm 5.68$ \\
Punch girth (cm) & $73.14 \pm 6.85$ \\
Clearance at udder (cm) & $22.77 \pm 2.68$ \\
Clearance at sternum (cm) & $24.43 \pm 2.38$ \\
Pelvic triangle area (square cm) & $462.65 \pm 138.71$ \\
Distance between tuber coxae bones (cm) & $11.38 \pm 1.18$ \\
Distance between tuber ischii bones (cm) & $4.56 \pm 0.54$ \\
\hline
\end{tabular}

were the next important factors for multiple litter size during pregnancy. Larger litter size was strongly influenced by higher parity and higher previous litter size. The results of the Hosmer and Lemeshow test register the goodness-offit of the selected logistic regression model where 0.1216 is a probability value (Table 3 ). Higher age, body weight, parity and previous litter size have positive influence on multiple births in Black Bengal goats. These findings are in general agreement with the previous reports on does (Constantinou, 1989; Mellado et al., 1991; Amoah et al., 1996) and ewes (Laster et al., 1972; Smith, 1985; Gaskins et al., 2005). Though some genes have been identified for influencing litter size in goats (An et al., 2009; Chu et al., 2011; Feng et al., 2011), certain body weight along with desirable body condition at certain age and parity may be necessary for optimum metabolic requirements which in turn influence hypophyseal-pituitary-gonadal axis for more ovulation that ultimately determine the number of successful fertilization and subsequently litter size (Perry et al., 1991; Tummaruk et al., 2007). In earlier studies, body condition score, higher live weight, age, physical strength and less slopped rump angles were found to be associated with an increase possibility of multiple births in does (Constantinou, 1989; Mellado et al., 2008) and in ewes (Hall et al., 1994; Gonzalez et al., 1997; Gaskins et al., 2005; Aliyari et al., 2012). It may be assumed that the does with higher previous litter size may have potential to give multiple births in subsequent kidding. Goats with longer neck length have showed to give multiple births. Since neck length may also be adjusted with age and body weight, it can't be ruled out whether neck length is a heritable character for the incidence of multiple births in Black Bengal goat. On the other hand, different linear traits have been suggested to be valuable tools in breeding programmes for some likelihood of productive and reproductive traits in goats (Wiggans and Hubbard, 2001), in sheep (Snowder, 2002) and in dairy cattle (Royal et al., 2002), because of the moderate to high heritability of some linear traits (Luo et al., 1997).

Table 4 lists the factors that influenced likelihood of litter size $>1$. Body weight $(>20.5 \mathrm{~kg})$, withers height $(>48.85 \mathrm{~cm})$ and parity $(>2.31)$ were associated with four times increased likelihood of multiple litter size. Previous litter size $(>1.65)$, distance between tuber coxae bones $(>11.38 \mathrm{~cm})$, neck length $(>22.78 \mathrm{~cm})$ registered three times more chances of multiple litter size. Does with $>2.69$ years age, $>54.86 \mathrm{~cm}$ body length, $>50.67 \mathrm{~cm}$ croup height and $>4.56 \mathrm{~cm}$ distance between tuber ischii bones were two times more likely to have multiple litter size. The odd ratio (<1) for clearance at udder measurement indicated an

Table 3. Summary of stepwise logistic selection of various traits influencing litter size in meat-type, prolific Black Bengal goats in India

\begin{tabular}{llccc}
\hline Step & Trait entered & DF & Score Chi-square & Pr.> Chi square $^{1}$ \\
\hline 1 & Withers height & 1 & 46.0132 & $<0.0001$ \\
2 & Distance between tuber coxae bones & 1 & 13.1773 & 0.0003 \\
3 & Body weight & 1 & 2.5079 & 0.1133 \\
4 & Neck length & 1 & 3.6537 & 0.0559 \\
5 & Body length & 1 & 2.5711 & 0.1088 \\
6 & Previous litter size & 1 & 1.3312 & 0.2586 \\
7 & Distance between tuber ischii bones & 1 & 1.368 & 0.2422 \\
8 & Croup height & 1 & 2.3705 & 0.1236 \\
9 & Parity & 1 & 1.608 & 0.2048 \\
10 & Clearance at udder & 1 & 1.9078 & 0.1672 \\
11 & Age & 1 & 2.0224 & 0.155 \\
\hline
\end{tabular}

${ }^{1}$ The Pr.>Chi square is 0.1216 at 8 d.f. and value of Chi square is 12.7277 as per Hosmer and Lemeshow Goodness-of-Fit test. 
Table 4. Summary of logistic regression model of the influence of various traits associated with litter size during pregnancy in meattype, prolific Black Bengal goats in India

\begin{tabular}{|c|c|c|c|c|c|}
\hline Item & $\mathrm{N}$ & $\begin{array}{l}\text { Litter size } \\
(\text { Mean } \pm \text { SD })\end{array}$ & Odds ratio estimate & $\begin{array}{l}\text { 95\% wald confidence } \\
\text { limits }\end{array}$ & p-value \\
\hline \multicolumn{6}{|c|}{ Withers height $(\mathrm{cm})$} \\
\hline$<48.85$ & 186 & $1.55 \pm 0.54$ & 1.000 & $2.532-6.352$ & $<0.0001$ \\
\hline$>48.85$ & 200 & $1.92 \pm 0.52$ & 4.003 & & \\
\hline \multicolumn{6}{|c|}{ Distance between tuber coxae bones $(\mathrm{cm})$} \\
\hline$<11.38$ & 187 & $1.57 \pm 0.53$ & 1.000 & $2.126-5.265$ & $<0.0001$ \\
\hline$>11.38$ & 199 & $1.90 \pm 0.54$ & 3.346 & & \\
\hline \multicolumn{6}{|c|}{ Body weight $(\mathrm{cm})$} \\
\hline$<20.50$ & 192 & $1.55 \pm 0.53$ & 1.000 & 2.753-7.088 & $<0.0001$ \\
\hline$>20.50$ & 194 & $1.94 \pm 0.52$ & 4.417 & & \\
\hline \multicolumn{6}{|c|}{ Neck length $(\mathrm{cm})$} \\
\hline$<22.78$ & 175 & $1.56 \pm 0.53$ & 1.000 & $2.102-5.149$ & $<0.0001$ \\
\hline$>22.78$ & 211 & $1.89 \pm 0.54$ & 3.290 & & \\
\hline \multicolumn{6}{|c|}{ Body length $(\mathrm{cm})$} \\
\hline$<54.86$ & 163 & $1.56 \pm 0.51$ & 1.000 & $1.806-4.361$ & $<0.0001$ \\
\hline$>54.86$ & 223 & $1.87 \pm 0.56$ & 2.806 & & \\
\hline \multicolumn{6}{|c|}{ Previous litter size (number) } \\
\hline$<1.65$ & 158 & $1.56 \pm 0.56$ & 1.000 & $2.169-5.293$ & $<0.0001$ \\
\hline$>1.65$ & 228 & $1.87 \pm 0.52$ & 3.389 & & \\
\hline \multicolumn{6}{|c|}{ Distance between tuber ischii bones $(\mathrm{cm})$} \\
\hline$<4.56$ & 179 & $1.62 \pm 0.53$ & 1.000 & $1.332-3.179$ & 0.0011 \\
\hline$>4.56$ & 207 & $1.85 \pm 0.56$ & 2.058 & & \\
\hline \multicolumn{6}{|c|}{ Croup height $(\mathrm{cm})$} \\
\hline$<50.67$ & 192 & $1.61 \pm 0.56$ & 1.000 & $1.778-4.353$ & $<0.0001$ \\
\hline$>50.67$ & 194 & $1.87 \pm 0.53$ & 2.782 & & \\
\hline \multicolumn{6}{|c|}{ Parity (number) } \\
\hline$<2.31$ & 235 & $1.60 \pm 0.55$ & 1.000 & $2.466-6.890$ & $<0.0001$ \\
\hline$>2.31$ & 151 & $1.95 \pm 0.51$ & 4.122 & & \\
\hline \multicolumn{6}{|c|}{ Clearance at udder $(\mathrm{cm})$} \\
\hline$<22.77$ & 184 & $1.76 \pm 0.54$ & 1.000 & $0.521-1.231$ & 0.3114 \\
\hline$>22.77$ & 202 & $1.72 \pm 0.58$ & 0.801 & & \\
\hline \multicolumn{6}{|l|}{ Age (yr) } \\
\hline$<2.69$ & 239 & $1.65 \pm 0.57$ & 1.000 & $1.724-4.560$ & $<0.0001$ \\
\hline$>2.69$ & 147 & $1.89 \pm 0.51$ & 2.804 & & \\
\hline
\end{tabular}

inverse association of such factor with the likelihood of multiple fetuses. The increased likelihood of bearing multiple fetuses for certain increased measurements in body length, withers height, croup height, distance between tuber coxae bones and distance between tuber ischii bones in pregnant goats could be due to enlargement of the body size during pregnancy to make room for twin or triplet fetuses. Physical strength has been implicated in an increase likelihood of multiple births in does (Mellado et al., 2008) and ewes (Hall et al., 1994). An inverse relationship between clearance at udder measurement and the likelihood of multiple fetuses suggests downward movement of udder in pregnant goats carrying multiple fetuses. Thus, phenotypic variation could be quite attractive for screening the goats bearing single or multiple fetuses.

\section{IMPLICATIONS}

A clear distinction between the pregnant goats bearing single and multiple fetuses is very necessary to the goat keepers for taking proper care of the goats carrying multiple fetuses and achieving economical benefit out of prolificacy trait. The present study generates the basic measurements of descriptive linear traits in meat type, prolific breed like Black Bengal goats. The older does $(>2.69$ years) with the history of larger previous litter size $(>1.65)$, higher parity $(>2.31)$ and more body weight $(>20.5 \mathrm{~kg})$ are associated with an increase likelihood of multiple litter size. This study 
also indicates a positive relationship between litter size and some body linear type traits. Neck length $(>22.78 \mathrm{~cm})$, body length $(>54.86 \mathrm{~cm})$, withers height $(>48.85 \mathrm{~cm})$, croup height $(>50.67 \mathrm{~cm})$, distance between tuber coxae bones $(>11.38 \mathrm{~cm})$ and distance between tuber ischii bones $(>4.56$ $\mathrm{cm})$ show an increased chance of carrying multiple fetuses. Hence, these body linear traits could be used for discriminating the goats bearing multiple fetuses from the goats bearing single fetus.

\section{ACKNOWLEDGEMENTS}

The work was supported by the National Fund for Basic, Strategic and Frontier Application Research in Agriculture (NFBSFARA) of Indian Council of Agricultural Research (ICAR), New Delhi, India.

The authors would like to express their sincere thanks to Indian Council of Agricultural Research, New Delhi, India for providing financial assistance under National Fund for Basic, Strategic and Frontier Application Research in Agriculture (project no. NFBSRA/PCN/AP-06/2006-07) to carry out the study. The necessary supports during the project work extended by the Director, ICAR Research Complex for North East Hill Region, Barapani, Meghalaya, India are duly acknowledged. The authors wish to thank the farmers for their regular help and cooperation during the investigation in the field.

\section{REFERENCES}

Abdelgafar, R. M., A. O. Bakhiet, and B. H. Ahmed. 2007. Bmode real-time ultrasonography for pregnancy diagnosis and fetal number in Saanen goats. J. Anim. Vet. Adv. 6:702-705.

Acharya, R. M. 1982. Sheep and goat breeds of India, FAO animal production and health paper 30, pp. 1-190. FAO, United Nations, Rome.

Aliyari, D., M. M. Moeini, M. H. Shahir, and M. A. Sirjani. 2012. Effect of body condition score, live weight and age on reproductive performance of Afshari ewes. Asian J. Anim. Vet. Adv. 7: 904-909.

Amoah, E. A., S. Gelaye, P. Guthrie, and C. E. Rexroad. 1996. Breeding season and aspects of reproduction of female goats. J. Anim. Sci. 74:723-728.

An, X. P., D. Han, J. X. Hou, G. Li, J. G. Wang, M. M. Yang, Y. X. Song, G. Q. Zhou, Y. N. Wang, L. Ling, Q. M. Yan, and B. Y. Cao. 2009. GnRH gene polymorphisms and their effects on reproductive performance in Chinese goats. Small Rumin. Res. 85:130-134.

Chu, M. X., Z. H. Wu, T. Feng, G. L. Cao, L. Fang, R. Di, D. W. Huang, X. W. Li, and N. Li. 2011. Polymorphism of GDF9 gene and its association with litter size in goats. Vet. Res. Commun. 35: 329-336.

Constantinou, A. 1989. Genetic and environmental relationships of body weight, milk yield and litter size in Damascus goats. Small Rumin. Res. 2:163-174.

Feng, T., C. X. Geng, X. Z. Lang, M. X. Chu, G. L. Cao, R. Di, L.
Fang, H. Q. Chen, X. L. Liu, and N. Li. 2011. Polymorphisms of caprine $G D F_{9}$ gene and their association with litter size in Jining Grey goats. Mol. Biol. Rep. 38:5189-5197.

Gaskins, C. T., G. D. Snowder, and M. K. Westman. 2005. Influence of body weight, age and weight gain on fertility and prolificacy in four breeds of ewe lambs. J. Anim. Sci. 83: 1680-1689.

Gonzalez, R. E., D. Labuonora, and A. J. E. Russel. 1997. The effects of ewe live weight and body condition score around mating on production from four sheep breeds in extensive grazing systems in Uruguay. Anim. Sci. 64:139-145.

Hall, D. G., A. R. Gilmour, and N. M. Fogarty. 1994. Variation in reproduction and production of poll dorset ewes. Australian J. Agric. Res. 45:415-425.

Hassan, M. M., S. M. Niaz Mahmud, S. K. M. Azizul Islam, and O. Faruk Miazi. 2007. A comparative study on reproductive performance and productivity of the Black Bengal and crossbred goat at Atrai, Bangladesh. Univ. J. Zool. Rajshahi Univ. 26:55-57.

Karen, A., B. E. Amiri, J. F. Beckers, J. Sulon, M. A. M. Taverne, and O. Szenci. 2006. Comparison of accuracy of transabdominal ultrasonography, progesterone and pregnancyassociated glycoproteins tests for discrimination between single and multiple pregnancy in sheep. Theriogenology 66: 314-322.

Khanum, S. A., M. Hussain, and R. Kausar. 2007. Assessment of reproductive parameters in female Dwarf goat (Capra hircus) on the basis of progesterone profiles. Anim. Reprod. Sci. 102: 267-275.

Laster, D. B., H. A. Glimp, and G. E. Dickerson. 1972. Factors affecting reproduction in ewe lambs. J. Anim. Sci. 35:79-83.

Luo, M. F., G. R. Wiggans, and S. M. Hubbard. 1997. Variance component estimation and multitrait genetic evaluation for type traits of dairy goats. J. Dairy Sci. 80:594-600.

Mellado, M., R. H. Foote, and E. Borrego. 1991. Lactational performance, prolificacy and relationship to parity and body weight in crossbred native goats in north Mexico. Small Rumin. Res. 6:167-174.

Mellado, M., J. Mellado, M. Valencia, and W. Pittroff. 2008. The relationship between linear type traits and fertility traits in high-yielding dairy goats. Reprod. Domest. Anim. 43:599-605.

Moallem, U., A. Rozov, E. Gootwine, and H. Honig. 2012. Plasma concentrations of key metabolites and insulin in late-pregnant ewes carrying 1 to 5 fetuses. J. Anim. Sci. 90:318-324.

Perry, R. C., L. R. Corah, R. C. Cochran, W. E. Beal, J. S. Stevenson, J. E. Minton, D. D. Simms, and J. R. Brethour. 1991. Influence of dietary energy on follicular development, serum gonadotropins, and first postpartum ovulation in suckled beef cows. J. Anim. Sci. 69:3762-3773.

Rahman, M. A., S. M. M. Rahman, M. A. Jalil, S. Nasiruddin, and M. M. Rahman. 2006. Molecular characterization of Black Bengal and Jamunapari goat breeds by RAPD markers. Am. J. Anim. Vet. Sci. 1:17-22.

Royal, M. D., J. E. Pryce, J. A. Woolliams, and A. P. F. Flint. 2002. The genetic relationship between commencement of luteal activity and calving interval, body condition score, production, and linear type traits in Holstein-Friesian dairy cattle. J. Dairy Sci. 85:3071-3080.

Sahoo, A. K., S. Pan, M. S. Tantia, and S. P. S. Ahlawat. 2005. 
Bengal Goat. West Bengal University of Animal and Fishery Sciences, Kolkata and National Bureau of Animal Genetic Resources, Karnal, India.

SAS 9.3., 2012. Foundation for Microsoft Windows, SAS Institute Inc., Cary, NC.

Smith, J. F. 1985. Protein, energy and ovulation rate. In: Genetics of Reproduction in Sheep (Ed. R. B. Land and D. W. Robinson). Butterworth, Boston, MA, USA. pp. 349.

Snowder, G. D. 2002. Composite trait selection for improving lamb production. Sheep Goat Res. J. 17:42-49.

Tummaruk, P., W. Tantasuparuk, M. Techakumphu, and A. Kunavongkrit. 2007. Age, body weight and backfat thickness at first observed oestrus in crossbred Landrace $\times$ Yorkshire gilts, seasonal variations and their influence on subsequence reproductive performance. Anim. Reprod. Sci. 99:167-181.
Wiggans, G. R. and S. M. Hubbard. 2001. Genetic evaluation of yield and type traits of dairy goats in the United States. J. Dairy Sci. 84:E69-E73.

Yakubu, A., A. E. Salako, I. G. Imumorin, A. O. Ige, and M. O. Akinyemi. 2010. Discriminant analysis of morphometric differentiation in the West African Dwarf and Red Sokoto goats. South African J. Anim. Sci. 40:381-387.

Zeshmarani, S., K. C. Dhara, A. K. Samanta, R. Samanta, and S. C. Majumder. 2007. Reproductive performance of goats in eastern and north-eastern India. Livest. Res. Rural Dev. 19(8): no. 114. http://www.lrrd.org/lrrd19/8/zesh19114.htm. Accessed January 27, 2014. 